Vol.3 No.1 Hal. 101-111

Juni 2020

\title{
Uji Komposisi Zat Pengatur Tumbuh Terhadap Pertumbuhan Eksplan Pisang Barangan (Musa paradisiaca L.) Pada Media MS Secara in vitro
}

\author{
Rahmad Setia Budi, \\ Staf Pengajar Agroteknologi Fakultas Pertanian UISU
}

Rsbudi69@yahoo.com

\begin{abstract}
ABSTRAK
Perbanyakan konvensional pisang secara umum melalui anakan (sucker) dan belahan bonggol (corm), namun bibit yang dihasilkan dengan cara ini menghasilkan sedikit anakan dan membutuhkan waktu relatif lama, pertumbuhan tidak seragam sehingga penanaman skala besar akan sulit dilakukan. Perbanyakan melalui kultur jaringan pada pisang barangan telah dilakukan, hingga diperoleh bibit bermutu baik (seragam dan bebas patogen) dalam jumlah lebih banyak dan cepat. Keberhasilan menginisiasi pembentukan kalus dan tunas merupakan langkah awal untuk menghasilkan planlet dengan multiplikasi yang tinggi. Penelitian ini dilaksanakan di laboratorium kultur jaringan UPT. Balai Benih Induk Gedung Johor Dinas Pertanian Provinsi Sumatera Utara. Tujuan penelitian untuk mengetahui pengaruh beberapa konsentrasi ZPT: (1). NAA (Naphthaleneacetic acid) dan BAP (Benzylamino purin) terhadap pertumbuhan eksplan pisang barangan secara kultur in vitro. (2). BA (Benzyl Adenin) dan IBA (Indole Butyric Acid). Rancangan penelitian yang digunakan adalah Rancangan Acak Lengkap (RAL) Faktorial. Hasil penelitian menunjukkan bahwa pengaruh konsentrasi NAA dan BAP; BA dan IBA terhadap pertumbuhan dan perkembangan eksplan tampak terutama dimulai pada minggu ke-2 setelah aplikasi hingga minggu ke-12. Konsentrasi BAP dan kombinasi konsentrasi NAA dan BAP serta konsentrasi BA dn IBA dan interaksinya tidak berpengaruh nyata terhadap persentase tumbuh, jumlah tunas, panjang tunas, dan bobot tunas.
\end{abstract}

Kata Kunci : : Eksplan, kultur in vitro, pisang barangan, zat pengatur tumbuh (NAA, BAP, BA, dan IBA)

\begin{abstract}
Conventional propagation of bananas in general through saplings (sucker) and parts of the tuber (corm), but the seeds produced in this way produces little puppies and requires a relatively long time, growth is not uniform so that large-scale cultivation would be difficult to do. Propagation through the tissue culture banana has been done, to obtain good quality seed (uniform and free of pathogens) in the amount of more and faster. The success initiate the formation of callus and shoots a preliminary step to produce plantlets with a high multiplication. This study was conducted in tissue culture laboratory UPT. Balai Benih Induk Gedung Johor Dinas Pertanian Sumatera Utara. The aim of research to determine the effect of several concentrations of PGR: (1). NAA (Naphthaleneacetic acid) and BAP (Benzylamino purine) on the growth of banana explants in vitro culture. (2). BA (Benzyl adenine) and IBA (Indole Butyric Acid). The study design used was completely randomized design (CRD) factorial. The results showed that the effect of NAA and BAP; BA and IBA on growth and development of explants looked especially starting at week 2 after application until the 12th week. The concentration of BAP and NAA concentrations and combinations of BAP and IBA and BA concentration and interaction did not significantly affect the percentage grows, the number of shoots, shoot length and weight of shoots
\end{abstract}

Keywords : Explant, in vitro culture, barangan banana, plant growth regulator (NAA, BAP, BA and IBA). 
Setia Budi R : Uji Komposisi Zat Pengatur Tumbuh Terhadap Pertumbuhan Eksplan Pisang Barangan (Musa paradisiaca L.) Pada Media MS Secara In Vitro .

\section{PENDAHULUAN}

\section{Latar Belakang}

Tanaman pisang (Musa paradisiaca L.) termasuk famili Musaceae, adalah buah-buahan yang berasal dari Asia Tenggara, tersebar diseluruh dunia, termasuk komoditi hortikultura yang penting dan sudah ada sejak lama menjadi mata dagangan yang memiliki reputasi internasional. Pisang termasuk keluarga musaceae, salah satu anggota ordo scitamineae (Suhardiman, 1997; dan Anonimus, 2013). Manfaat pisang antara lain: buahnya dikonsumsi, bonggolnya dapat diolah menjadi makanan, daunnya dijadikan pembungkus dan pelepahnya dapat dijadikan bahan serat (Supriyadi dan Satuhu, 2002). Pisang barangan (Musa acuminate Colla) berasal dari Sumatera Utara dan menyebar diseluruh Indonesia. Selama ini pisang barangan belum begitu dikembangkan, meskipun sangat digemari masyarakat. Akar hingga daunnya dapat dimanfaakan untuk kepentingan manusia. Buah pisang dikonsumsi dalam bentuk segar (tanpa pengolahan), karena rasanya enak, manis, dan beraroma. Jenis tanaman pisang dapat digolongkan menjadi tiga jika didasarkan pada saat buah pisang tersebut dapat dimakan yaitu golongan pisang yang dapat dimakan buahnya setelah masak seperti pisang ambon, pisang barangan, pisang raja dan lainnya.(Widya, 2008). Pada tahun 1942, Indonesia terkenal sebagai negara pengekspor pisang, tetapi kini tidak terjadi lagi walaupun peluang untuk itu besar. Hal ini dikarenakan kontinuitas dan kualitas produksi pisang di Indonesia tidak memenuhi standar sesuai dengan persyaratan dunia (Agustin, 2005). Khusus untuk permintaan buah pisang barangan juga terus meningkat terutama di kota-kota besar Sumatera Utara dan Jakarta, sehingga beberapa petani telah membudidayakannya secara komersial. Bercocok tanam pisang barangan sangat berbeda dengan tanaman pisang lainnya, karena pisang memerlukan pemeliharaan intensif guna mendapatkan produksi yang tinggi dan kualitas buah yang baik (Balai Pengkajian Teknologi Pertanian Sumatera Utara, 2008).Salah satu tanaman pisang yang mempunyai potensi yang tinggi dan berpeluang untuk dikembangkan adalah pisang barangan (Zebua, 2015). Salah satu masalah utama yang dihadapi masyarakat Indonesia dalam budidaya tanaman pisang dan khususnya pisang barangan adalah teknik budidaya perbanyakan pisang. Tanaman pisang biasanya diperbanyak dengan cara vegetatif dengan menggunakan tunas anakan (sucker) yang tumbuh dari bonggol (corm) induknya anakan, karena tanaman pisang tidak dapat menghasilkan biji yang dapat berkembang menjadi tanaman baru, hanya menghasilkan sekitar 2-6 anakan, membutuhkan waktu relatif lama. Teknik pemindahan anakan pada perbanyakan pisang, menghasilkan tanaman tidak seragam, dapat membawa penyakit dan sulit didapatkan bahan tanaman dalam jumlah yang banyak (Purnomo, 2004). Setiap indukan pisang dapat menghasilkan 5-10 anakan sehat dalam tiap tahun (Levoire, 2000). Penanaman skala besar akan sulit dilakukan karena membutuhkan bibit dalam jumlah besar dan pertumbuhan yang seragam (Cahyono, 1995). Sehubungan dengan itu kebutuhan bibit ungul berkualitas, dalam jumlah banyak, dan tersedia secara kontinu setiap tahunnya merupakan masalah. Disamping faktor pertunasan yang rendah, perakaran sering menjadi masalah utama yang sulit dipecahkan. Masalah ini diharapkan dapat diatasi melalui teknik kultur in vitro, yaitu dapat diperoleh tanaman baru yang lengkap dan mempunyai sifat seperti induknya, diperoleh bibit bermutu baik (seragam dan bebas patogen), menghasilkan jumlah anakan dalam jumlah besar dan dalam waktu singkat (Gunawan, 1990; 1998). Umumnya jaringan meristematis merupakan bagian yang penting dijadikan sebagai bahan tanam. Pada perbanyakan mikro tanaman pisang, bahan tanam dapat berasal dari meristem/mata tunas (Al-Amin, et al., 2009; Marlin, 2010; Bhosale, et al., 2011).Menurut Gunawan (1998), dalam teknik kultur jaringan terdapat beberapa faktor penentu antara lain media tumbuh. Media tumbuh adalah komposisi unsur hara makro, unsur hara mikro, sumber besi, sumber karbon, vitamin, dan zat pengatur tumbuh (ZPT). Medium dasar MS (Murashige and Skoog, 1962) adalah yang paling luas penggunaannya dibandingkan dengan media dasar lainnya. Pertumbuhan dan perkembangan 
Setia Budi R : Uji Komposisi Zat Pengatur Tumbuh Terhadap Pertumbuhan Eksplan Pisang Barangan (Musa paradisiaca L.) Pada Media MS Secara In Vitro .

tanaman dikendalikan berbagai faktor dan berbagai reaksi kimia. Salah satu reaksi kimia yang cukup memegang peranan penting adalah hormon dan ZPT (Dartius, 2002). Di dalam kultur jaringan, kehadiran ZPT sangat nyata pengaruhnya. Bahkan menurut Zulkarnain (2009), menyatakan bahwa sangat sulit menerapkan tehnik kultur jaringan pada upaya perbanyakan tanaman tanpa melibatkan ZPT. Zat pengatur tumbuh yang biasa digunakan dapat berasal dari golongan auksin maupun sitokinin. Golongan auksin adalah IBA, IAA, NAA, dan 2,4-D. Sedangkan dari golongan sitokinin adalah Kinetin, Zeatin dan BA (Abidin, 1990). Auksin umumnya berfungsi terhadap pemanjangan sel, pembentukan kalus dan akar adventif serta menghambat pembentukan tunas aksilar, auksin yang sering dipakai dalam kultur jaringan adalah IAA (Indole Acetic Acid), 2,4-D (2,4 DichlorophenoxyAcetic Acid), IBA (Indole Butyric Acid) dan NAA (Naphtalen Acetic Acid) (Wattimena, 1987).Sitokinin adalah ZPT yang ditemukan pada tanaman oleh Haberlandt, fungsi sitokinin adalah pembelahan sel, pembesaran sel, menghambat penuaan bunga dan buah, dan deferensiasi akar dan tunas (Heddy, 1996).

\section{Rumusan Masalah}

Bibit pisang yang berkualitas dan baik masih sangat dibutuhkan bagi budidaya tanaman pisang, salah satunya dapat dihasilkan melalui Teknik kultur in vitro. Masalah utama dalam kultur jaringan adalah cara memproduksi kalus dan tunas secara massal dari eksplan yang digunakan, dikarenakan media dasar yang digunakan dalam kultur jaringan belum cukup untuk mensuplai semua kebutuhan pertumbuhan jaringan, maka untuk itu perlu ditambahkan ZPT yang berfungsi merangsang dan mendorong pertumbuhan eksplan

\section{Tujuan Penelitian}

Penelitian ini bertujuan untuk menguji beberapa ZPT NAA, BAP, BA dan IBA terhadap pertumbuhan eksplan pisang barangan pada media MS secara In vitro

\section{METODE PENELITIAN}

\section{Tempat dan Waktu}

Penelitian dilaksanakan di laboratorium kultur jaringan UPT. Balai Benih Induk Gedung Johor Dinas Pertanian Pemerintah Provinsi Sumatera Utara, Medan

\section{Rancangan Penelitian atau Model}

Rancangan penelitian yang digunakan adalah Rancangan Acak Lengkap (RAL) Faktorial, yaitu: (1) Uji NAA dan BAP dengan 2 faktor, yaitu konsentrasi NAA (A) dengan 4 taraf yaitu: A0 (kontrol), A1 (0.5 mg/l), A2 (1.0 mg/l) dan A3 (1.5 mg/l), dan faktor konsentrasi BAP (B) dengan 4 taraf, yaitu: B0 (kontrol), B1 (1.5 mg/l), B2 (3.0 mg/l) dan B3 (4.5 mg/l). Media yang digunakan adalah media MS penuh; (2) Uji BA dan IBA dengan 2 faktor, yaitu konsentrasi BA (A) dengan 4 taraf yaitu: B0 (kontrol), B1 (1.5 mg/l), B2 (3.0 mg/l) dan B3 $(4.5 \mathrm{mg} / \mathrm{l})$, dan faktor konsentrasi IBA (I) dengan 4 taraf, yaitu: I0 (kontrol), I1 (0.5 mg/l), $\mathrm{I} 2(1.0 \mathrm{mg} / \mathrm{l})$ dan $\mathrm{I} 3(1.5 \mathrm{mg} / \mathrm{l})$. Media yang digunakan adalah media MS penuh.

\section{Bahan dan Peralatan}

Penelitian ini menggunakan eksplan anakan pisang barangan yang sehat dengan bonggol berwarna putih bersih berukuran tinggi $30-40 \mathrm{~cm}$ yang diperoleh dari Desa Siguci, Kecamatan: STM. Hilir, Kabupaten Deli Serdang Provinsi Sumatera Utara.Bahan lainnya yaitu bahan pembuat media lengkap, antara lain:hara makro, hara mikro vitamin, gula, air 
Setia Budi R : Uji Komposisi Zat Pengatur Tumbuh Terhadap Pertumbuhan Eksplan Pisang Barangan (Musa paradisiaca L.) Pada Media MS Secara In Vitro .

suling, bahan pemadat agar untuk pembuatan media MS, dan ZPT. Zat pengatur tumbuh yang biasa digunakan dapat berasal dari golongan auksin maupun sitokinin, yaitu: NAA, BAP, BA, dan IAA.

\section{Peralatan}

Laminar air flow cabinet (LAFC), autoclave, petridish, erlenmeyer, becker glass, pinset, scapel, bunsen, wadah botol kultur, dan peralatan laboratorium lainnya, serta alat-alat pengamatan.

\section{Tahapan Penelitian Persiapan Eksplan}

Eksplan berupa bonggol pisang yang berumur 2-3 bulan dibersihkan dengan air mengalir dan diambil titik tumbuh direndam dalam larutan fungisida (benlate) selama 2-3 jam, kemudian bilas dengan air bersih sebanyak 3 kali. Titik tumbuh direndam ke dalam larutan clorox $20 \%$ dan dibiarkan selama 1 jam,lalu bilas dengan air steril sebanyak 3 kali. Pindahkan ke botol lain yang berisi clorox $10 \%$ selama 30 menit dan dibiarkan, kemudian dikeluarkan lalu bilas dengan air steril sebanyak 3 kali.

\section{Penanaman Eksplan}

Penanaman eksplan dilakukan dalam LAFC. Dari tunas diambil titik tumbuhnya (meristem) dipotong dengan ukuran $1,5 \mathrm{~cm}^{3}$ dan dimasukkan ke dalam petridish yang berisi akohol dan betadine. Kemudian eksplan ditanam ke dalam media yang telah disiapkan. Media yang digunakan adalah media dasar Murashige dan Skoog (1962) yang terdiri dari komponen hara makro, hara mikro, myoinositol dan asam amino. Masing-masing komponen media di larutkan dan diencerkan sesuai dengan kepekatan hara yang dibutuhkan dan ditambahkan dengan ZPT sesuai perlakuan.

\section{Peubah yang diamati}

Pengamatan meliputi persen eksplan yang tumbuh/ hidup, jumlah tunas, tinggi eksplan, bobot eksplan. Pengamatan dilakukan pada umur 2, 4, 6, 8, dan 12 minggu setelah dikulturkan.

\section{HASIL DAN PEMBAHASAN}

Hasil pengamatan menunjukkan persentase hidup jaringan eksplan yang tinggi. Beberapa teknik sterilisasi dilakukan untuk mendapatkan inokulasi yang steril untuk dikulturkan kembali sesuai dengan perlakuan. Penggunaan fungisida dan bakterisida yang sistemik ditujukan untuk menghilangkan kontaminasi dalam jaringan eksplan.Hasil pengamatan dan analisis data dapat dilihat pada uaraian berikut:

\section{Persentase Eksplan Hidup (\%) Pada Perlakuan ZPT (NAA, BAP, BA, IBA)}

Dari hasil penelitian terlihat bahwa persentase hidup eksplan tinggi (100\%), walaupun memerlukan waktu yang relatif lebih lama dalam membentuk kalus dan tunas. Respon tumbuh ditunjukkan dengan perubahan warna eksplan, kemudian diikuti dengan pembengkakan dan pemanjangan jaringan. Pada beberapa bagian eksplan menunjukkan gejala pencoklatan (browning) dan gejala ini terjadi pada tahap awal kultur, tetapi gejala ini berubah baik warna putih kecokelatan menjadi coklat kehijauan maupun bentuknya pada umur 4 mst.Terjadinya perubahan warna eksplan tidak berarti matinya jaringan, karena 
jaringan masih menunjukkan pertambahan ukuran. Perubahan warna disebabkan oleh keluarnya senyawa yang berasal dari jaringan terluka. Pertumbuhannya dipengaruhi oleh beberapa faktor, antara lain media tumbuh dan ukuran eksplan yang digunakan. Hasil analisis statistik menunjukkan bahwa perlakuan konsentrasi ZPT BA dan IBA serta interaksi keduanya berpengaruh tidak nyata terhadap jumlah eksplan yang tumbuh pada umur $2 \mathrm{mst}$. Perlakuan dosis ZPT BA dan ZPT IBA serta interaksi tidak berpengaruh nyata terhadap persentase tumbuh pisang barangan. Hasil penelitian dapat dilihat bahwa jumlah persentase hidup eksplan pisang barangan sangatlah tinggi (100\%), hal ini disebabkan media kultur sudah cukup untuk mendukung pertumbuhan eksplan sehingga ZPT BA dan ZPT IBA serta interaksinya tidak menunjukkan pengaruh terhadap pertumbuhannya. Eksplan yang hidup berkembang membentuk tunas, sedikit perakaran, pembesaran bonggol dan sebagian kecil statis. Respon awal dari jaringan adalah membesarnya eksplan yang dikulturkan, pada awal penanaman eksplan berwarna putih kehitaman. Terjadi perubahan warna eksplan tidak berarti matinya jaringan, karena jaringan masih menunjukkan pertambahan ukuran, diduga perubahan warna tersebut disebabkan oleh keluarnya senyawa-senyawa dari jaringan eksplan yang terluka selanjutnya berubah warna yang disebut dengan browning/pencoklatan. Browning ini disebabkan oleh senyawa fenol yang timbul akibat stress mekanik dari pelukaan pada waktu proses isolasi eksplan dari tanaman induk. Senyawa fenol tersebut bersifat toksik, menghambat pertumbuhan atau bahkan dapat mematikan jaringan eksplan (Edhi, 20013). Pencoklatan/browning ini dapat diatasi dengan melakukan subkultur pada waktu terjadinya browning. Penambahan arang aktif ke dalam media kultur seringkali dapat menghindari pembentukan inhibitor fenolat. Arang aktif menghilangkan pewarnaan dengan menyerap dan mengoksidasi fenol dan menginaktifkan peroksidase (Tisserat, 1979). Semua eksplan menunjukkan adanya pertumbuhan, pertumbuhan ini dipengaruhi oleh beberapa faktor, antara lain karena media tumbuhan yang digunakan, dimana pada medium yang digunakan tersedia nutrisi yang cukup untuk pertumbuhan eksplan. Pertumbuhan eksplan juga dipengaruhi oleh potongan jaringan eksplan yang digunakan serta ukuran eksplan, pada penelitian ini jaringan yang digunakan adalah jaringan meristem. Jaringan meristem adalah jaringan muda, dimana jaringan ini terdiri dari sel-sel yang selalu membelah dan ukuran eksplan berukuran kecil lebih kurang $1 \mathrm{~cm}$.

\section{Jumlah Tunas (buah) Pada Perlakuan ZPT (NAA, BAP, BA, IBA)}

Hasil analisis menunjukkan bahwa aplikasi ZPT NAA dan BAP serta interaksi kedua faktor perlakuan tidak berpengaruh nyata terhadap jumlah tunas pada umur 12 mst. Pemberian NAA menunjukkan pengaruh yang tidak nyata terhadap jumlah tunas eksplan pisang, tetapi terdapat perbedaan jumlah tunas eksplan pada setiap perlakuan. Jumlah tunas yang terbanyak terdapat pada perlakuan A3 $(1.5 \mathrm{mg} / \mathrm{l})$ yaitu 1.75 buah dan yang terendah pada perlakuan A0 (kontrol) yaitu 1.17 buah. Auksin adalah salah satu hormon yang tidak terlepas dari proses pertumbuhan dan perkembangan (growth and development) suatu tanaman, di dalam media berperan untuk merangsang pertumbuhan kalus, merangsang pembesaran sel serta pertumbuhan akar dan mengatur morfogenesis. (Abidin, 1990). Menurut Karjadi dan Buchory (2007) auksin sintetis, seperti NAA biasaya lebih efektif dibandingkan IAA, karena NAA tidak dirusak oleh IAA oksidase atau enzim lain, sehingga bisa bertahan lebih lama. Perlakuan pemberian BAP menunjukkan perbedaan yang tidak nyata terhadap jumlah tunas eksplan, tetapi terdapat perbedaan jumlah tunas eksplan pada setiap perlakuan. Jumlah tunas yang terbanyak diperoleh pada perlakuan B1 (1.5 mg/l) yaitu 1.81 buah dan terendah pada perlakuan B0 (kontrol) yaitu 1.17 buah. Pemberian BAP menunjukkan pertambahan jumlah tunas, semakin tinggi konsentrasi yang diberikan maka jumlah tunas akan terus meningkat, tetapi pertumbuhan jumlah tunas belum maksimal. Hal ini disebabkan karena BAP belum berperan dalam pembelahan sel dan morfogenesis (pertumbuhan akar dan tunas) 
dikarenakan faktor keseimbangan ZPT dan waktu yang mungkin terlalu singkat. BAP merupakan sitokinin buatan yang mempunyai sifat yang sama dengan sitokinin alamiah. Sitokinin memiliki fungsi untuk mengatur pertumbuhan melalui pembelahan sel, membantu mengawasi perkecambahan biji, mengatur transport auksin dan dalam kultur jaringan sitokinin berperan dalam pertumbuhan serta morfogenesis (Anonimus, 2013). Menurut Budi (1999), medium kultur yang hanya mengandung NAA saja berpengaruh tidak signifikan terhadap persentase eksplan dalam pembentukan tunas majemuk, dan pemberian BAP dengan konsentrasi tinggi ternyata menghambat pembentukan tunas. Berbeda halnya dengan penambahan NAA yang seimbang dapat memberikan pengaruh yang lebih baik pada pembentukan tunas tanaman. Hal ini didukung oleh George dan Sherrington (1984), apabila ketersedian sitokinin di dalam media kultur sangat terbatas maka pembelahan sel pada jaringan akan terhambat. Akan tetapi, apabila jaringan tersebut disubkulturkan pada medium dengan kandungan sitokinin yang memadai maka pembelahan sel akan berlangsung secara singkron sedangkan pada konsentrasi yang tinggi dapat menghambat pertumbuhan, meracuni bahkan mematikan tanaman. Perimbangan konsentrasi dan interaksi antara ZPT yang diberikan dalam media dan yang diproduksi oleh sel secara endogen akan menentukan perkembangan suatu kultur. Interaksi sitokinin dan auksin sangat dibutuhkan untuk pertumbuhan eksplan. Pierik (1987) dalam Zulkarnain (2009), menyatakan bahwa pada umumnya auksin meningkatkan pemanjangan sel, pembelahan sel, dan pembentukan akar adventif. Auksin berpengaruh pula untuk menghambat pembentukan tunas adventif dan tunas aksilar. Konsentrasi auksin yang rendah akan meningkatkan pembentukan akar adventif, sedangkan auksin konsentrasi tinggi akan merangsang pembentukan kalus dan menekan morfogenesis. Eksplan yang tidak membentuk kalus mengalami perubahan warna dari hijau menjadi coklat kemudian mati, hal ini dapat disebabkan karena timbulnya senyawa fenolik yang keluar dari eksplan tersebut. Peristiwa pencoklatan ini merupakan suatu proses perubahan adaptif bagian tanaman akibat adanya pengaruh seperti respon dari bekas perlukaan pada eksplan. Terjadinya pencoklatan pada jaringan adalah karena aksi oksidasi plofenol yang disintesis akibat dari oksidasi jaringan ketika terluka. (Robbiani, 2010).

Hasil analisis statistik menunjukkan bahwa konsentrasi BA dan IBA serta interaksi keduanya berpengaruh tidak nyata terhadap jumlah tunas yang tumbuh. Pada perlakuan pemberian IBA tidak berpengaruh nyata terhadap jumlah tunas pisang barangan. Berdasarkan data di atas pemberian IBA meskipun tidak berbeda nyata namun jumlah tunas akibat pemberian IBA umumnya di atas kontrol (meningkat). Hal ini menunjukkan meskipun media telah memenuhi kebutuhan tanaman untuk pertumbuhan namun masih ada respon meningkatnya jumlah tunas, semakin tinggi pemberian ZPT IBA ternyata jumlah tunas menurun sehingga sama dengan kontrol. Jumlah tunas terbanyak diperoleh pada perlakuan $I_{1}(0,5 \mathrm{mg} / \mathrm{l})$ dan $\mathrm{I}_{2}(1,0 \mathrm{mg} / \mathrm{l})$ yaitu 2,67 tunas dan yang terendah jumlah tunas pada perlakuan $\mathrm{I}_{\mathrm{o}}$ (kontrol) yaitu 2,33 tunas dan $\mathrm{I}_{3}(1,5 \mathrm{mg} / \mathrm{l})$ yaitu 2,33 tunas. Pemberian ZPT BA tidak menunjukkan pertambahan jumlah tunas. Tetapi terdapat perbedaan jumlah tunas pada setiap perlakuan. Jumlah tunas terbanyak diperoleh pada perlakuan $\mathrm{B}_{1}(1.5 \mathrm{mg} / \mathrm{l})$ yaitu 3,00 tunas dan yang terendah pada perlakuan $\mathrm{B}_{2}(3,0 \mathrm{mg} / \mathrm{l})$ dan $\mathrm{B}_{3}(4,5 \mathrm{mg} / \mathrm{l})$ yaitu 2,00 tunas. Perlakuan dosis ZPT BA tidak berpengaruh nyata terhadap jumlah tunas. Menurut George dan Sherrington (1984), apabila ketersedian sitokinin di dalam media kultur sangat terbatas maka pembelahan sel pada jaringan akan terhambat. Akan tetapi, apabila jaringan tersebut disubkulturkan pada medium dengan kandungan sitokinin yang memadai maka pembelahan sel akan berlangsung secara singkron sedangkan pada konsentrasi yang tinggi dapat menghambat pertumbuhan, meracuni bahkan mematikan tanaman. Zat pengatur tumbuh BA banyak digunakan untuk memacu penggandaan tunas karena mempunyai aktivitas yang kuat dibanding kinetin. BA mempunyai struktur dasar yang sama dengan 
Setia Budi R : Uji Komposisi Zat Pengatur Tumbuh Terhadap Pertumbuhan Eksplan Pisang Barangan (Musa paradisiaca L.) Pada Media MS Secara In Vitro .

kinetin tetapi lebih efektif karena BA mempunyai gugus benzi. Umumnya tanaman memiliki respon yang lebih baik terhadap BA dibandingkan terhadap kinetin sehingga BA lebih efektif untuk produksi tunas. IBA adalah salah satu hormon yang mempunyai manfaat lain seperti menambah daya kecambah, merangsang perkembangan buah, mencegah kerontokan, pendorong kegiatan kambium dan lain lain. Suatu tumbuhan yang diberikan hormon IBA akan mengalami pembentukan akar lebih cepat. IBA mempunyai sifat yang lebih baik dan efektif dari pada IAA dan NAA. Dengan demikian IBA paling sesuai untuk merangsang aktivitas perakaran karena kadar kimianya lebih stabil (Anonimus, 2013).

\section{Tinggi Eksplan (cm) Pada Perlakuan ZPT (NAA, BAP, BA, IBA)}

Hasil analisis menunjukkan bahwa perlakuan NAA berpangaruh nyata terhadap tinggi eksplan pisang, tetapi tidak berpengaruh nyata terhadap perlakuan BAP dan interaksi kedua faktor tersebut. hal ini dapat dilihat pada Tabel 1.

Tabel 1. Rataan tinggi eksplan pisang barangan $(\mathrm{cm})$ dengan perlakuan NAA dan BAP pada umur 12 Mst.

\begin{tabular}{llllll}
\hline \multirow{2}{*}{ Perlakuan } & \multicolumn{5}{c}{ BAP } \\
\cline { 2 - 6 } & B0 & B1 & B2 & B3 & Rataan \\
\hline NAA & 2.04 & 1.93 & 2.33 & 2.11 & $2.10 \mathrm{C}$ \\
A0 & 2.04 & 2.43 & 2.51 & 2.13 & $2.28 \mathrm{C}$ \\
A1 & 2.37 & 4.31 & 3.00 & 5.84 & 3.88 A \\
A2 & 2.73 & 2.73 & 4.67 & 2.97 & 3.28 B \\
A3 & & & & & 3.26 \\
Rataan & 2.29 & 2,85 & 3.13 & & \\
\hline
\end{tabular}

Keterangan : Angka yang diikuti huruf yang tidak sama menunjukkan berbeda nyata pada taraf $1 \%$ berdasarkan uji DMRT.

Tabel 1 dapat dilihat bahwa perlakuan konsentrasi NAA menunjukkan perbedaan yang nyata terhadap tinggi eksplan pisang. Eksplan tertinggi terdapat pada perlakuan A2 (1 mg/l) yaitu $3.88 \mathrm{~cm}$, yang berbeda nyata terhadap pengaruh perlakuanA3 $(1.5 \mathrm{mg} / \mathrm{l})$ yaitu $3.28 \mathrm{~cm}$ dan pengaruh perlakuan A1 $(0.5 \mathrm{mg} / \mathrm{l}) 2.28 \mathrm{~cm}$. Hubungan tinggi eksplan pisang terhadap pemberian NAA dapat dilihat pada Gambar 1 di bawah ini. Hal ini dikarenakan pengaruh NAA memberikan efek sinergis terhadap pertumbuhan eksplan pisang untuk pemanjangan sel membentuk tunas. Auksin berfungsi mendorong perpanjangan sel dengan cara mempengaruhi dinding sel melalui dua tahap, yaitu fase pembelahan sehingga sel akan mengalami kerenggangan dan penebalan. Pertumbuhan pada meristem ujung menghasilkan sel-sel baru sehingga mengakibatkan bertambahnya tinggi atau panjang tunas. Sedangkan sitokinin dapat mendorong pembelahan sel dalam bagian ujung dari tunas. Perlakuan pemberian konsentrasi BAP berpengaruh tidak nyata terhadap tinggi eksplan pisang, tetapi terdapat perbedaan tinggi pada setiap perlakuan. Eksplan yang tertinggi terdapat pada perlakuan B3 (4.5 mg/l) yaitu $3.26 \mathrm{~cm}$ dan yang terendah pada perlakuan B0 (kontrol) yaitu $2.29 \mathrm{~cm}$. Hal ini terjadi karena kandungan BAP lebih rendah, sehingga pertumbuhan tinggi tunas menjadi terhambat. Interaksi antara kedua perlakuan konsentrasi NAA dan BAP menunjukkan pengaruh tidak nyata terhadap tinggi eksplan (Gambar 2 a, 2 b, dan 2 c). 
Setia Budi R : Uji Komposisi Zat Pengatur Tumbuh Terhadap Pertumbuhan Eksplan Pisang Barangan (Musa paradisiaca L.) Pada Media MS Secara In Vitro .

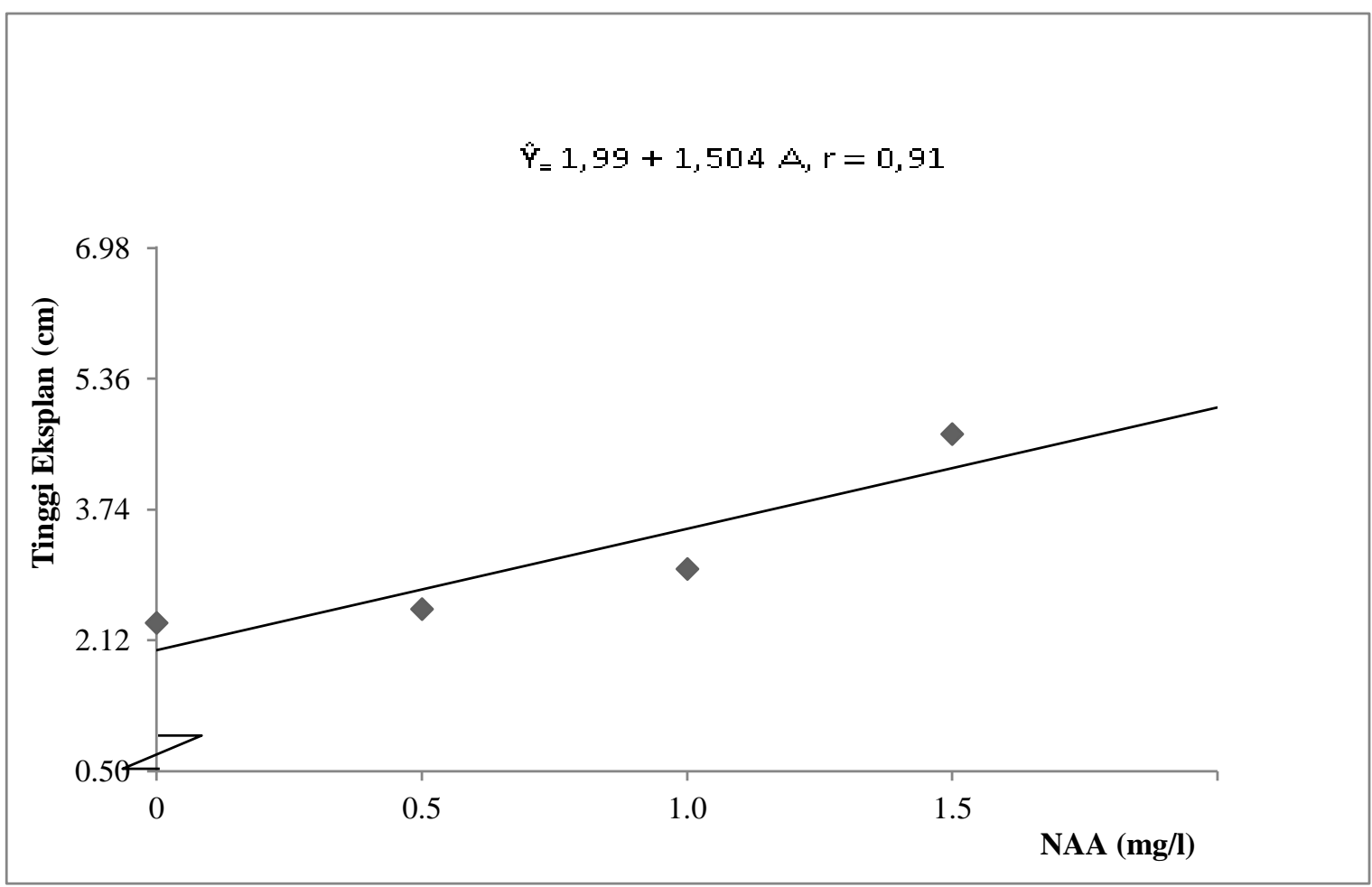

Gambar 1. Hubungan tinggi eksplan pisang barangan umur 12 mst terhadap pemberian NAA

Umumnya auksin meningkatkan pemanjangan sel, pembelahan sel, dan pembentukan akar adventif, dalam medium kultur auksin dibutuhkan untuk meningkatkan embryogenesis somatik pada kultur suspensi sel. Konsentrasi auksin yang tinggi akan merangsang pembentukan kalus dan menekan morfogenesis (George and Sherrington, 1984).
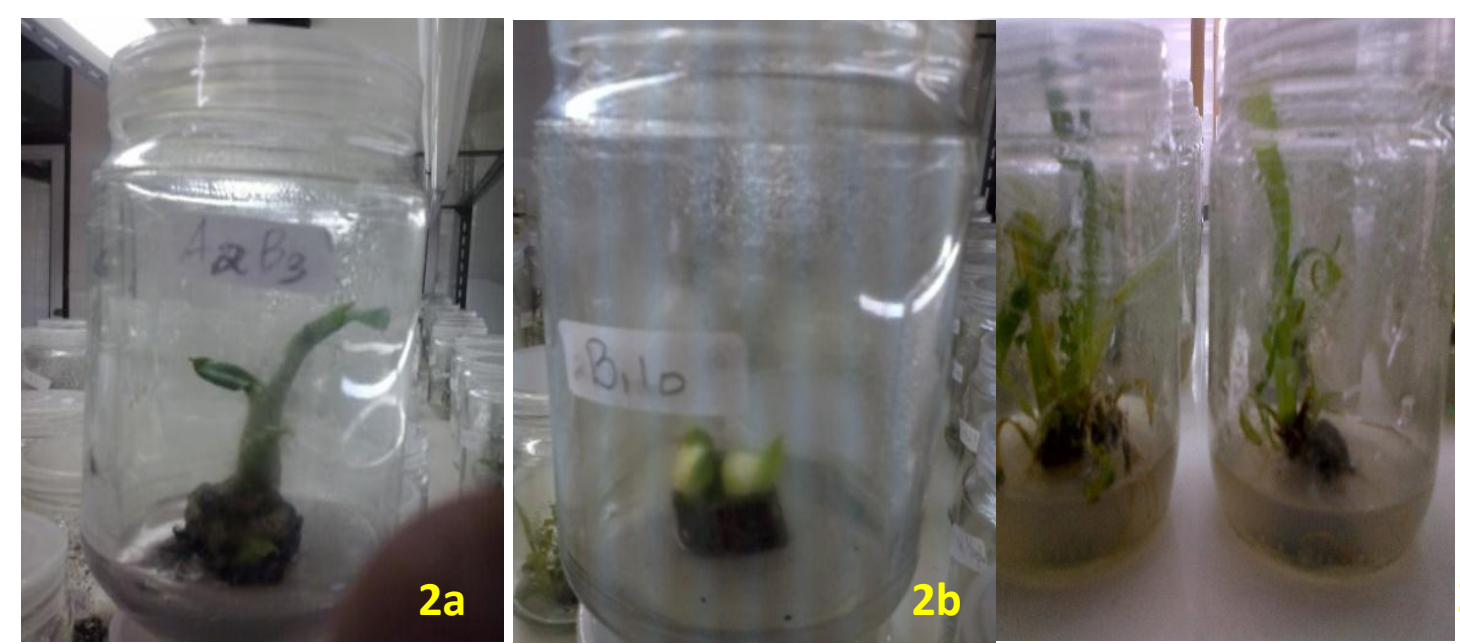

Gambar 2a. Eksplan pisang pada perlakuan NAA dan BAP; 2b. BA dan IBA pada 12 MST; dan 2c. Planlet pisang barangan siap dipindah ke lapangan

\section{Bobot Eksplan (g) Pada Pemberian ZPT (NAA, BAP, BA, dan IBA)}

Hasil analisis menunjukkan bahwa perlakuan konsentrasi NAA, BAP, BA, dan IBA serta interaksi kedua faktor perlakuan tidak berpengaruh nyata terhadap bobot eksplan pisang barangan pada umur 12 mst. Pada pemberian NAA menunjukkan pengaruh yang tidak nyata terhadap bobot eksplan pisang barangan, tetapi terdapat perbedaan bobot eksplan pada setiap perlakuan. Bobot eksplan terberat terdapat pada perlakuan A3 $(1.5 \mathrm{mg} / \mathrm{l})$ yaitu $4.38 \mathrm{~g}$ dan 
yang terendah pada $\mathrm{A} 0$ (kontrol) yaitu $2.54 \mathrm{~g}$. Hal ini dikarenakan konsentrasi NAA belum mencukupi sehingga kurang meningkatkan pembelahan sel untuk dalam proses pembengkakan eksplan walaupun terjadi bertambahnya ukuran bobot eksplan pada setiap penambahan konsetrasi NAA. Selain itu ukuran eksplan yang digunakan dalam penelitian ini relatif lebih kecil, sehingga perkembangan sel menjadi lebih lambat. Perlakuan pemberian BAP menunjukkan perbedaan yang tidak nyata terhadap bobot eksplan pisang barangan, tetapi terdapat perbedaan pada setiap perlakuan. Bobot eksplan terberat pada perlakuan B2 (3 mg/l) yaitu $4.17 \mathrm{~g}$ dan terendah pada perlakuan B3 $(4.5 \mathrm{mg} / \mathrm{l})$ yaitu $2.69 \mathrm{~g}$.

Hal ini dikarenakan konsentrasi BAP belum mencukupi untuk proses pembelahan sel dan pemanjangan sel. Demikian juga dengan interaksinya, kombinasi antara NAA dan BAP tidak berpengaruh nyata terhadap bobot eksplan pisang barangan. Pierik (1987) menyatakan bahwa pada umumnya auksin meningkatkan pemanjangan sel, pembelahan sel, dan pembentukan akar adventif. Auksin berpengaruh pula untuk menghambat pembentukan tunas adventif dan tunas aksilar. Konsentrasi auksin yang rendah akan meningkatkan pembentukan akar adventif, sedangkan auksin konsentrasi tinggi akan merangsang pembentukan kalus dan menekan morfogenesis.Pada perlakuan BA tidak berpengaruh nyata terhadap bobot eksplan pisang barangan. Berdasarkan data diketahui bahwa pemberian BA tidak menunjukkan pertambahan bobot eksplan karena pemberian ZPT BA rata-rata menunjukkan angka di bawah kontrol. Tetapi terdapat perbedaan bobot eksplan pada setiap perlakuan. Bobot eksplan terberat pada perlakuan $B_{1}(1,5 \mathrm{mg} / \mathrm{l})$ yaitu $6,08 \mathrm{~g}$ dan terendah pada perlakuan $\mathrm{B}_{3}(4,5 \mathrm{mg} / \mathrm{l})$ yaitu $5,38 \mathrm{~g}$. Dari data tersebut terlihat bahwa pemberian $\mathrm{BA}$ $1,5 \mathrm{mg} / \mathrm{l}$ terjadi pertambahan bobot eksplan namun selanjutnya semakin tinggi konsentarsi BA bobot eksplan semakin turun malah dibawah kontrol. Pada perlakuan IBA tidak berpengaruh nyata terhadap bobot eksplan pisang barangan. Berdasarkan data bahwa pemberian IBA meskipun tidak berbeda nyata namun bobot eksplan diakibatkan pemberian IBA umumnya di atas kontrol (meningkat). Hal ini menunjukkan meskipun media telah memenuhi kebutuhan tanaman untuk pertumbuhan namun masih ada respon meningkatnya bobot eksplan, tetapi semakin tinggi pemberian IBA ternyata bobot eksplan menurun sehingga mendekati kontrol. Dari penanaman eksplan pertamakali, bobot eksplan rata rata adalah 0,90 g. Eksplan berkembang menjadi kalus sehingga semakin bertambah besar, ini menandakan proses pembentukan kalus berlangsung terhadap eksplan. Namun terdapat perbedaan bobot eksplan pada setiap perlakuan, bobot eksplan terberat diperoleh pada perlakuan $\mathrm{I}_{2}(1,0 \mathrm{mg} / \mathrm{l})$ yaitu $5,92 \mathrm{~g}$ dan terendah pada perlakuan $\mathrm{I}_{0}$ (kontrol) yaitu $5,73 \mathrm{~g}$ pada umur 12 mst. Pada umumnya interaksi antara BA dan IBA menunjukkan penurunan bobot eksplan hanya kombinasi $\mathrm{B}_{3} \mathrm{I}_{2}$ saja yang terjadi peningkatan bobot eksplan. Hal ini disebabkan kurang sinergisnya antara ZPT BA dan IBA. Pertumbuhan eksplan juga dipengaruhi oleh potongan jaringan eksplan yang digunakan serta ukuran eksplan yang digunakan dimana eksplan yang berukuran besar beresiko terkontaminasi lebih tinggi dibandingkan dengan ukuran yang lebih kecil, tetapi kemampuan hidupnya lebih besar/tumbuh lebih cepat. Sebaliknya eksplan yang berukuran kecil kemungkinan terkontaminasinya lebih rendah namun pertumbuhannya lebih lambat.

\section{KESIMPULAN}

Dari percobaan ini dapat diambil beberapa kesimpulan sebagai berikut:

1. Pemberian ZPT NAA hanya berpengaruh nyata terhadap tinggi eksplan pisang barangan. Sedangkan pemberian NAA dan BAP serta interaksinya menunjukkan pengaruk tidak nyata pada parameter lainnya seperti persentase hidup, jumlah tunas dan bobot eksplan. Jumlah tunas yang terbanyak diperoleh pada perlakuan B1 (1.5 $\mathrm{mg} / \mathrm{l})$ yaitu 1.81 buah 
Setia Budi R : Uji Komposisi Zat Pengatur Tumbuh Terhadap Pertumbuhan Eksplan Pisang Barangan (Musa paradisiaca L.) Pada Media MS Secara In Vitro .

2. Perlakuan konsentrasi ZPT BA dan IBA serta interaksi keduanya berpengaruh tidak nyata terhadap jumlah tunas yang tumbuh. Jumlah tunas terbanyak dihasilkan pada pemberian ZPT BA diperoleh pada perlakuan $\mathrm{B}_{1}(1.5 \mathrm{mg} / \mathrm{l})$ yaitu 3,00 tunas, jumlah tunas terbanyak antara kombinasi ZPT BA dan IBA pada perlakuan kombinasi $\mathrm{B}_{3} \mathrm{I}_{3}$ $(4,5 \mathrm{mg} / \mathrm{l}+1,5 \mathrm{mg} / \mathrm{l})$ yaitu 2,67 tunas. Bobot eksplan terberat diperoleh pada pemberian ZPT BA diperoleh pada perlakuan $\mathrm{B}_{1}(1,5 \mathrm{mg} / \mathrm{l})$ yaitu $6,08 \mathrm{~g}$, bobot eksplan terberat antara kombinasi ZPT BA dan IBA pada perlakuan kombinasi $\mathrm{B}_{3} \mathrm{I}_{2}$ $(4,5 \mathrm{mg} / \mathrm{l}+1,0 \mathrm{mg} / \mathrm{l})$ yaitu $5,94 \mathrm{~g}$.

3. Untuk keberhasilan suatu kultur perlu perhatian khusus dalam penentuan jenis, jumlah, keseimbangan ZPT, dan komposisi kimia medium, serta ukuran eksplan dan alokasi waktu yang dibutuhkan dalam melihat respon pertumbuhan dan perkembangan suatu kultur.dikembangkan.

\section{DAFTAR PUSTAKA}

Abidin, Z. 1990. Dasar-Dasar Pengetahuan Tentang Zat Pengatur Tumbuh. Angkasa, Bandung.

Agustin, Widya. 2005. Pemuliaan Tanaman Pisang dengan Kultur Anther. Dikutip dari : http// www. Pemuliaan Tanaman Pisang.com. diakses bulan Januari 2016.

Al-Amin, M.D., M.R. Karim, M.R. Amin, S. Rahman, and A.N.M. Mamun. 2009. In vitro micropropagation of banana (Musa spp.). Bangladesh J. Agril. R. 34(4): 645-659.

Ambarwati, A.D. 1987. Induksi Kalus dan Differensiasi pada Kultur Jaringan Gnetum gnemon L. Fakultas Biologi. Universitas Gadjah Mada. Yogyakarta.

Anonimus, 2013. Jenis-Jenis dan Fungsi Hormon .http://www.limaratus.com.diakses pada tanggal 26 januari 2014. Medan .

Balai Pengkajian Teknologi Pertanian Sumatera Utara, 2008. Teknologi Penanaman Pisang Barangan Sistem Dua Jalur (Double Row). Balai Pengkajian Teknologi Pertanian Sumatera Utara. Medan.

Bhosale, U.P., S.V. Dubhashi, N.S. Mali, and H.P. Rathod. 2011. In vitro shoot multiplication in different species of banana. Asian J. of Plant Science and Research. $1(3): 23-27$.

Budi, R.S., Liew Teik Kooi, Christoper K.H. Teo. 1999. Produksi Tunas Majemuk Secara In Vitro Pohon Sentang (Azadirachta excelsa Linn). Jurnal penelitian Pertanian; Volume 18, No 2, Desember 1999.

Cahyono, B. 1995. Pisang, Budidaya dan Analisis UsahaTani. Kanisius.Yogjakarta.

Dartius. 2002. Fisiologi Tumbuhan. Fakulatas Pertanian UISU, Medan.

Edhi, S. 2013. Cara Mudah Memahami dan Menguasai Kultur Jaringan Skala Rumah Tangga. IPB Press. Bogor.

George, E.F. and P.D. Sherrington. 1984.Plant Propagation by Tissue Culture: Handbook and Directory of Commercial Laboratories. Great Britain by Eastern Press, Reading, Berks.

Gomez, A. K And A.A. Gomez. 1996. Prosedur Statistik Untuk Penelitian Pertanian. UIPress, Jakarta.

Gunawan, L.W. 1998. Regenerasi pucuk dan embrio somatic dalam kultur aseptik Jati (Tectona grandis L.F.). Hayati, 5 (2): 44-49.

Heddy, S. 1996. Hormon Tumbuhan. Jakarta. PT Grafindo Persada.

Herwin, Aditya. 2013. Budidaya Tanaman Pisang. Dikutip Dari: (wordpress.com/2014/01/27bab-pendahuluan-latar-belakang-piasang). 
Setia Budi R : Uji Komposisi Zat Pengatur Tumbuh Terhadap Pertumbuhan Eksplan Pisang Barangan (Musa paradisiaca L.) Pada Media MS Secara In Vitro .

Karjadi, AK, dan A. Buchory. 2007. Pengaruh NAA dan BAP Terhadap Pertumbuhan Jaringan Meristem Bawang Putih Pada Media B5. Balai Penelitian Tanaman Sayuran. Lembang, Bandung.

Marlin, 2010. Regenerasi In Vitro Planlet Pisang Ambon Curup Bebas Penyakit Layu Fusarium. Prosiding pada Seminar Nasional dan Rapat Tahunan Dekan Bidang Pertanian BKS Barat.

Murashige, T. Dan F. Skoog. 1962. A revised medium for rapid growth and bio assay with tobacco tissue cultures. Physiologia Plantarum 15.

Pierik, R.L.M. 1987. In Vitro Culture of Higher Plants. The Netherlands: Kluwer Academic Publishers, Dordrecht.

Purwanto, D. 1991. Pengaruh ukuran bahan tanam terhadap keberhasilan perbanyakan beberapa varietas pisang (Musa paradisiaca L.) dengan Metode Kultur Jaringan. Skripsi. Fakultas Pertanian UNIBRAW. Malang.

Purnomo, U. 2004. Pengaruh BAP dan Ekstrak Pisang Raja Terhadap pertumbuhan Pisang barangan Merah Secara In vitro. Skripsi. FP.UMSU, Medan.

Radian. 1992. Penggunaan Air Kelapa Dalam Media Kultur Jaringan Pisang (Musa paradisiaca L). Program Pasca Sarjana. UGM. Program KDK UNBRAW.

Robbiani, D., 2010. Pengaruh Kombinasi Naphthalene Acetic Acid (NAA) dan Kinetin pada Kultur in vitro Eksplan Daun Tembakau (Nicotiana tabacum L. var. Prancak 95). Institut Teknologi Sepuluh Nopember Surabaya.

Setiyoko, B. 1995. Kultur Meristem Tanaman Pisang (Musa paradisiaca L.) Kultivar Ambon untuk Memperoleh Tanaman yang Bebas Cucumber Mosaic Virus. Skripsi. Fakultas Biologi UGM. Yogyakarta.

Sitohang, Nurdin. 2004. Kultur Meristem Pisang Barangan Pada Media MS. Skripsi.Unika Thomas, Medan.

Sriyanti, D.P. dan A.Wijayani. 1994. Teknik Kultur Jaringan. Yayasan Kansius. Yogyakarta.

Supriyadi, L. dan S. Satuhu. 2002. Pisang. Penebar Swadaya Jakarta.

Tisserat, B., 1979. Propagation of Date Palm (Phoenix dactylifera L.) in vitro. J. Exp. Bot. 30:1275- 1283 .

Wattimena, G.A, 1987. Multipikasi Tanaman Hortikultura secara Kultur Jaringan. Laboratorium Kultur Jaringan Tanaman. PAU Bioteknologi IPB. Bogor.

Wetter, L.R. dan F. Constabel. 1991. Metode Kultur Jaringan Tanaman. ITB. Bandung. Widya,

Y. 2008. Pedoman Bertanam Buah Pisang.

Tim Nima Karya Tani. Bandung

Zebua, D., 2015. Induksi Tunas Pisang Barangan (Musa Acuminata L.) Asal Nias Utara Melalui Kultur Jaringan dengan Pemberian 2,4-D dan Kinetin. Tesis. Program Pascasarjana. Fakultas Matematika dan Ilmu Pengetahuan Alam. Universitas Sumatera Utara.

Zullkarnain. 2009. Solusi Perbanyakan Tanaman Budidaya, Kultur Jaringan Tanaman. Bumi Aksara. Jakarta. 